\title{
PERAN KUALITAS LABA DALAM MEMEDIASI PENGARUH KONSERVATISME AKUNTANSI TERHADAP NILAI PERUSAHAAN
}

\author{
Kezia Octaviani $^{1)}$, Sugi Suhartono ${ }^{2)^{*}}$ \\ ${ }^{1)}$ Program Studi Akuntansi, Institut Binis dan Informatika Kwik Kian Gie \\ ${ }^{2)}$ Dosen Program Studi Akuntansi, Institut Binis dan Informatika Kwik Kian Gie \\ Email :sugi.suhartono@kwikkiangie.ac.id
}

Diterima 24 Agustus 2020 / Disetujui 25 Februari 2021

\begin{abstract}
The investor's valuation of the company's performance often only sees the stock price. High share price reflects the high value of the company as well. However, low share prices do not necessarily indicate the company's performance is poor. This research aims to analyse and know the role of quality of profit in the mediation of the influence of conservatism accounting on the firm value. Sampling techniques are performed by purposive sampling methods. Sample of 60 manufacturing companies that have been listed on the Indonesia Stock Exchange for the period 2016-2018.. The data analysis techniques undertaken are coefficient of similarity, descriptive statistics, classical assumption test, and linear regression analysis, including F-Test, T-Test, and coefficient of determination test. And to make the role of the quality of profit as a variable intervening, it is done using the analysis of pathways and Sobel tests to test indirect influences. The results showed that the quality of profit has a positive and significant effect on the firm value, accounting conservatism has a positive and significant effect on the quality of profit, while the accounting conservatism is not proven directly affect the value of the company. Based on the analysis of the track and The Sobel test shows that earnings quality can mediate the effect of accounting conservatism on firm value.
\end{abstract}

Keywords: Accounting Conservatism, Earnings Quality, Firm Value

ABSTRAK: Penilaian investor terhadap kinerja perusahaan seringkali hanya melihat dari harga saham. Harga saham yang tinggi mencerminkan nilai perusahaan yang tinggi. Namun, harga saham yang rendah tidak selalu mengindikasikan kinerja perusahaan tersebut kurang baik. Tujuan dari penelitian ini adalah untuk menganalisis peran kualitas laba dalam mediasi pengaruh konservatisme akuntansi terhadap nilai perusahaan. Pengambilan sampel menggunakan teknik non probalility sampling dengan metode purposive sampling. Sampel sebanyak 60 perusahaan manufaktur yang telah didaftarkan di BEI (Bursa Efek Indonesia) periode tahun 2016-2018. Teknik analisis data antara lain uji kesamaan koefisien, statistika deskriptif, uji asumsi klasik, dan analisis regresi linear yang meliputi uji $\mathrm{F}$, uji t, dan uji koefisien determinasi. Pengujian peran kualitas laba sebagai variable intervening, dilakukan dengan analisis jalur dan uji Sobel untuk menguji pengaruh tidak langsung. Hasil penelitian membuktikan bahwa kualitas laba berpengaruh positif dan signifikan terhadap nilai perusahaan, konservatisme akuntansi berpengaruh positif dan signifikan terhadap kualitas laba, sedangkan konservatisme akuntansi tidak terbukti berpengaruh secara langsung terhadap nilai perusahaan. Berdasarkan hasil path analysis dan Uji Sobel menunjukkan bahwa kualitas laba dapat memediasi pengaruh konservatisme akuntansi terhadap nilai perusahaan.

Kata kunci: Konservatisme Akuntansi, Kualitas Laba, Nilai Perusahaan.

\section{Pendahuluan}

Nilai perusahaan merupakan suatu persepsi yang dimiliki investor mengenai tingkat keberhasilan suatu perusahaan yang dicerminkan dengan harga saham. (Fatimah et.al 2019). Harga saham yang semakin tinggi maka nilai perusahaan juga semakin tinggi. Peningkatan nilai perusahaan ini akan meningkatkan reaksi pasar karena anggapan bahwa return yang diterima akan semakin tinggi dan risiko yang ditanggung investor akan semakin rendah. Investor merasa lebih yakin untuk membeli saham yang mempunyai harga tinggi. Laporan 
kinerja perusahaan yang disajikan dalam laporan keuangan dapat digunakan oleh pengguna laporan keuangan, khususnya para pemegang saham dalam mengambil keputusan-keputusan strategis. Perusahaan yang dianggap berkualitas mempunyai nilai perusahaan yang tinggi, dan hal ini merupakan daya tarik investor untuk berinvestasi. Salah satu tujuan utama perusahaan didirikan adalah meningkatkan nilai perusahaan dan untuk meningkatkan kemakmuran pemegang saham (Brigham dan Gapenski dalam Basuki dan Siregar (2019). Harmono dalam Mandey et al. (2017) menyatakan bahwa terdapat 4(empat) indikator pengukuran nilai perusahaan, yaitu antara lain price to book value ratio $(P B V)$, price earning ratio $(P E R)$, earning per share (EPS), dan analisis Tobin's $Q$.

Laporan keuangan merupakan informasi yang sangat penting bagi para investor. Hal ini membuat manajemen perusahaan berupaya menunjukkan laba yang semakin berkualitas yang bertujuan untuk meningkatkan nilai perusahaan. Salah satu upaya manajemen dalam meningkatkan kualitas labanya adalah antara lain dengan menerapkan konsep konservatisme akuntansi (pudence). Menurut Watts (2003) konservatisme akuntansi adalah prinsip kehati-hatian dalam pencatatan dan penyajian laporan keuangan, yaitu agar perusahaan tidak segera mengakui aset dan laba, namun segera mungkin mengakui kerugian dan utang yang kemungkinan akan terjadi. Penerapan konservatisme akuntansi tidak berarti semua pendapatan harus diterima sebelum pendapatan tersebut diakui. Pendapatan sebagai informasi good news tersebut diverifikasi terlebih dahulu apakah nilainya lebih tinggi dibandingkan dalam hal pengakuan terhadap kerugian (bad news) (Basu, 1997). Prinsip konservatisme akuntansi ini masih dianggap debatable. Menurut Monahan (1999) prinsip konservatisme dapat menyebabkan informasi keuangan yang ada dalam laporan keuangan bisa menjadi bias, sehingga tidak dapat menjadi alat bagi pengguna laporan keuangan dalam mengevaluasi risiko perusahaan. Konservatisme akuntansi dianggap dapat meningkatkan asimetri informasi dan mengarahkan investor untuk membuat kesimpulan yang salah sehingga berpotensi menurunkan nilai perusahaan karena kondisi perusahaan tidak dapat sesungguhnya diketahui (Penman dan Zhang, 2002). Di sisi lain, pendukung konservatisme akuntansi menyatakan bahwa prinsip konservatisme akuntansi menghasilkan laporan keuangan lebih berkualitas, dikarenakan prinsip ini dapat mencegah perusahaan untuk membesarbesarkan laba sehingga laba dan aktiva yang diatampilkan dalam laporan keuangan tidak overstate (Watts, 2003). Penelitian Hartono dan Sabeni (2014), Augustine (2016), Wijaya dan Hasniar (2016), dan Mukminah et al. (2018) menunjukkan konservatisme akuntansi berpengaruh siginifikan positif terhadap nilai perusahaan. Sedangkan penelitian Manik (2018) dan Basuki dan Siregar (2019) menunjukkan konservatisme akuntansi berpengaruh siginifikan negatif terhadap nilai perusahaan. Hasil penelitian lain yang dilakukan oleh Yenti dan Syofyan (2013) serta penelitian Jusny (2014) menyatakan bahwa konservatisme akuntansi tidak berpengaruh terhadap nilai perusahaan.

Investor menggunakan informasi laba yang dipublikasikan oleh perusahaan sebagai bahan pertimbangan dalam mengambil keputusan investasinya. Laba yang diharapkan oleh para investor adalah laba yang berkualitas tanpa adanya praktik manajemen laba. Manajemen laba merupakan salah satu cara dalam memilih metode akuntansi yang dilakukan oleh manajer untuk mencapai pelaporan laba tertentu (Scott, 2015:445). Menurut teori keagenan, manajemen laba terjadi karena adanya perbedaan kepentingan (interest) antara manajemen (agent) dan pemilik perusahaan (prinsipal) yang dapat menimbulkan masalah keagenan dan menurunkan nilai perusahaan.

Machdar et al. (2017) menyatakan bahwa kualitas laba merupakan salah satu faktor penting untuk mengetahui nilai perusahaan. Namun, dalam praktiknya seringkali investor hanya memerhatikan laba perusahaan yang besar. Padahal laba yang besar tersebut belum tentu berkualitas 
karena terdapat kemungkinan pihak manajemen memanipulasi laba tersebut. Menurut Siallagan dan Machfoedz (2006), rendahnya kualitas laba dapat menimbulkan kesalahan dalam pengambilan keputusan bagi para investor maupun kreditur, sehingga nilai perusahaan akan berkurang. Penelitian yang lain juga telah dilakukan oleh Siallagan (2009), Isti'adah (2015), Jonathan dan Machdar (2018), serta Rahayu dan Sari (2018) menunjukkan bahwa kualitas laba berpengaruh signifikan positif terhadap nilai perusahaan. Sedangkan penelitian Rustan et al. (2014), Mawati et al. (2017), Nafiah et al. (2018), dan Wulanda dan Aziza (2019) menyatakan bahwa kualitas laba tidak memengaruhi nilai perusahaan secara signifikan.

Dalam penerapan metode akuntansi di perusahaan, seringkali terjadi intervensi manajemen selama proses penyajian dan pelaporan laporan keuangan (Gunawan et al., 2015). Intervensi tersebut berupa praktik earnings management yang dilakukan untuk meningkatkan kemakmuran individu atau untuk meningkatkan besarnya laba perusahaan. Konservatisme akuntansi dapat membatasi tindakan oportunis manajer yang hanya memaksimalkan kepentingannya sendiri sehingga perusahaan dapat menghasilkan kualitas laba yang lebih baik atau lebih berkualitas, dikarenakan adanya penurunan praktik manajemen laba.(Sari, 2019).

Prinsip konservatisme akuntansi yang diterapkan dalam rangka meningkatkan nilai perusahaan dapat terganggu oleh karena manajemen laba yang menurunkan kualitas laba tersebut. Sebaliknya, ketika penerapan konservatisme akuntansi didukung dengan kualitas laba yang baik maka nilai perusahaan dapat meningkat karena hal ini dapat menjadi daya tarik yang kuat bagi investor. Hasil penelitian Asri dan Habbe (2017), Sugianto dan Sjarief (2018), Lara et al. (2019), serta Li (2019) menyatakan bahwa konservatisme akuntansi berpengaruh positif terhadap kualitas laba. Sedangkan penelitian terdahulu oleh Penman dan Zhang (2002), Soraya dan Harto (2014), Fauzi et al. (2015), dan Ruwanti (2016) menunjukkan hasil yang berbeda yaitu konservatisme akuntansi berpengaruh negatif dan signifikan terhadap kualitas laba. Hasil penelitian yang bertolak belakang diperoleh Pasaribu et al. (2016) yang tidak menemukan pengaruh antara konservatisme akuntansi dengan kualitas laba.

Prinsip kehati-hatian atau konservatisme dapat menurunkan konflik keagenan di antara para pemegang saham dengan pihak manajemen karena tindakan oportunistik manajer yang hanya menguntungkan dirinya saja dapat dicegah. Konservatisme akuntansi berarti menerapkan verifikasi tinggi dalam menyampaikan good news, dibandingkan bad news bagi para investor maupun pengguna laporan keuangan lainnya. Prinsip akuntansi konservatif yang telah diterapkan dalam laporan keuangan dianggap sebagai sinyal positif oleh investor bahwa manajemen atau agen telah melakukan langkah-langkah konservatif untuk mencegah tindakan membesarbesarkan aset dan pendapatan perusahaan. Sinyal positif investor akan dapat meningkatkan dan menaikkan nilai perusahaan yang tercermin melalui harga saham di pasar modal. Penelitian Zulfiara dan Ismanto (2019) menyatakan konservatisme akuntansi berpengaruh positif terhadap nilai perusahaan karena konservatisme akuntansi menghasilkan laporan keuangan yang lebih berkualitas dan tidak overstated sehingga investor menilai perusahaan tersebut memiliki nilai yang tinggi.

Dalam penyusunan laporan keuangan, manajemen dapat memilih metode akuntansi dari alternatif-alternatif yang tersedia. Melalui kebebasan memilih tersebut, tindakan oportunistik manajemen dapat terjadi seperti tindakan memanipulasi laba yang dapat menurunkan kualitas laba dengan tujuan memperoleh bonus lebih tinggi. Perusahaan yang memiliki laba berkualitas, tanpa adanya manipulasi dari manajer, maka laba tersebut merupakan sinyal positif yang akan direspon baik oleh investor. Sinyal tersebut menjadi good news yang dapat menurunkan asimetri informasi dan konflik keagenan. Pasar akan menunjukkan reaksi yang kuat terhadap 
saham perusahaan yang mengindikasikan nilai perusahaan meningkat. Penelitian Jonathan dan Machdar (2018) menyatakan bahwa semakin rendah manipulasi laba yang mengindikasikan laba berkualitas akan meningkatkan nilai perusahaan. Penelitian Theophillus dan Akintoye (2018) juga menyatakan bahwa kualitas laba mempunyai pengaruh positif terhadap nilai perusahaan di Nigeria. Investor perlu memerhatikan kualitas laba perusahaan sebelum melakukan investasi.

Konservatisme akuntansi yang diterapkan dalam perusahaan dapat berperan dalam mengurangi atau meminimalisir konflik keagenan dan membatasi tindakan oportunistik yang dilakukan oleh manajer. Tindakan oportunisnik tersebut merupakan manajemen laba yaitu tindakan memanipulasi laba yang dapat menurunkan kualitas laba perusahaan. Kehati-hatian manajer dalam mengakui pendapatan akan menyebabkan laba yang dilaporkan tidak overstated. Investor tidak hanya menginginkan laba yang besar secara kuantitas, namun juga laba yang berkualitas sehingga risiko yang ditanggung oleh investor semakin rendah. Dengan penerapan prinsip konservatisme akuntansi, manajemen laba dapat dikurangi sehingga kualitas laba perusahaan semakin tinggi. Penelitian Li (2019) menyebutkan bahwa agen atau manajemen perusahaan seringkali melakukan manipulasi laporan keuangan dengan meningkatkan penjualan. Penerapan konservatisme akuntansi pada perusahaanperusahaan di Shanghai dan Shenzhen dapat mencegah tindakan manajemen laba tersebut sehingga meningkatkan kualitas laba perusahaan.

Dalam menerapkan metode akuntansi, seringkali terdapat intervensi dari pihak manajemen sebagai agen bertanggung jawab atas kemakmuran prinsipal yaitu pemegang saham. Intervensi tersebut dapat berupa tindakan manajemen laba yaitu memanipulasi besarnya laba perusahaan. Penerapan konservatisme akuntansi untuk meningkatkan nilai perusahaan dapat terganggu, karena tindakan manajemen laba dapat menurunkan kualitas laba tersebut. Padahal, konservatisme akuntansi yang masih dianggap kontroversial dapat meningkatkan nilai perusahaan dengan didukung oleh kualitas laba yang baik. Artinya, ketika perusahaan menerapkan prinsip konservatisme akuntansi dan menghasilkan laba yang mencerminkan kinerja perusahaan sesungguhnya, maka prinsip konservatisme akuntansi tersebut dapat mendorong investor berinvestasi. Secara tidak langsung meningkatnya investasi yang dilakukan oleh para investor mengindikasikan peningkatan nilai perusahaan, yang disebabkan kualitas laba perusahaan.

Penelitian ini bertujuan mengetahui pengaruh secara langsung konservatisme (prudence) akuntansi terhadap nilai perusahaan, pengaruh kualitas laba terhadap nilai perusahaan, konservatisme terhadap kualitas laba, dan pengaruh tidak langsung antara konservatisme akuntansi terhadap nilai perusahaan yang dimediasi oleh kualitas laba.

\section{Pengembangan Hipotesis}

\section{Pengaruh Konservatisme Akuntansi Terhadap Nilai Perusahaan}

Prinsip kehati-hatian (prudence) atau konservatisme dapat menurunkan konflik keagenan antara pemegang saham dengan pihak manajemen karena tindakan oportunistik manajer yang hanya menguntungkan dirinya saja dapat dicegah. Konservatisme akuntansi berarti menerapkan verifikasi yang tinggi dalam penyampaian good news dibandingkan bad news bagi para investor sebagi salah satu user laporan keuangan. Penerapan prinsip akuntansi konservatif dalam laporan keuangan sebagai sinyal positif dari manajemen kepada investor bahwa manajemen telah bertindak konservatif untuk mencegah tindakan membersarbesarkan aset dan pendapatan perusahaan. Sinyal positif bagi investor menjadi pertimbangan untuk berinvestasi sehingga dapat meningkatkan nilai perusahaan yang tercermin melalui naiknya harga saham.. Penelitian Zulfiara dan Ismanto (2019) menyatakan konservatisme akuntansi 
berpengaruh positif terhadap nilai perusahaan karena konservatisme akuntansi menghasilkan laporan keuangan yang lebih berkualitas dan tidak overstated sehingga investor menilai perusahaan memiliki nilai yang tinggi. Penelitian Rizkiadi dan Vinola Herawaty (2020); Meilany dan Wahyu Nurul Hidayati (2020); Laila dan Delori Nancy Meyla (20200 menunjukkan bahwa konservatisme akuntansi (prudence) berpengaruh positif terhadap nilai perusahaan.

$\mathrm{Ha}_{1}$ : Konservatisme akuntansi (KONS) berpengaruh positif terhadap nilai perusahaan (NP).

\section{Pengaruh Kualitas Laba Terhadap Nilai Perusahaan}

Dalam penyusunan laporan keuangan, manajemen dapat memilih metode akuntansi dari alternatif-alternatif yang tersedia. Melalui kebebasan memilih tersebut, tindakan oportunistik manajemen dapat terjadi seperti tindakan memanipulasi laba yang dapat menurunkan kualitas laba dengan tujuan memperoleh bonus yang lebih tinggi. Jika perusahaan memiliki kualitas laba yang baik tanpa adanya manipulasi dari manajer, maka laba tersebut merupakan sinyal positif yang akan direspon baik oleh investor. Sinyal tersebut menjadi good news yang dapat menurunkan asimetri informasi dan konflik keagenan. Pasar akan menunjukkan reaksi yang kuat terhadap saham perusahaan yang mengindikasikan nilai perusahaan meningkat. Penelitian Jonathan dan Machdar (2018) menyatakan bahwa semakin rendah manipulasi laba yang mengindikasikan laba berkualitas akan meningkatkan nilai perusahaan. Penelitian Theophillus dan Akintoye (2018) juga menyatakan bahwa kualitas laba berpengaruh positif terhadap nilai perusahaan di Nigeria. Investor perlu memerhatikan kualitas laba perusahaan sebelum melakukan investasi.

$\mathrm{Ha}_{2}$ : Kualitas laba (KL) berpengaruh positif terhadap nilai perusahaan (NP).

\section{Pengaruh Konservatisme Akuntansi Terhadap Kualitas Laba}

Konservatisme akuntansi dapat berperan dalam konflik keagenan untuk meminimalisasi tindakan oportunistik yang dilakukan oleh manajer. Tindakan oportunisnik tersebut merupakan manajemen laba yaitu tindakan memanipulasi laba yang dapat menurunkan kualitas laba perusahaan. Kehati-hatian manajer dalam mengakui pendapatan akan menyebabkan laba yang dilaporkan tidak overstated. Investor tidak hanya menginginkan laba yang besar secara kuantitas, namun juga laba yang berkualitas sehingga risiko yang ditanggung oleh investor semakin rendah. Dengan penerapan prinsip konservatisme akuntansi, manajemen laba dapat dikurangi sehingga kualitas laba perusahaan semakin tinggi. Penelitian Li (2019) menyebutkan bahwa manajemen perusahaan seringkali memanipulasi laporan keuangan dengan meningkatkan penjualan. Penerapan konservatisme akuntansi pada perusahaanperusahaan di Shanghai dan Shenzhen dapat mencegah tindakan manajemen laba tersebut sehingga meningkatkan kualitas laba perusahaan. Menurut hasil penelitian Julianingsih, D. K. E. D., \& Yuniarta, G. A. (2020) menyatakan bahwa konservatime akuntansi mempengaruhi kualitas laba dengan arah positif.

$\mathrm{Ha}_{3}$ : Konservatisme akuntansi (KONS) berpengaruh positif terhadap kualitas laba (KL).

\section{Pengaruh Konservatisme Akuntansi Terhadap Nilai Perusahaan Melalui Kualitas Laba}

Dalam menerapkan metode akuntansi, seringkali terdapat intervensi dari pihak manajemen yang bertanggung jawab terhadap kemakmuran prinsipal yaitu pemegang saham. Intervensi tersebut dapat berupa tindakan manajemen laba yang memanipulasi besarnya laba perusahaan. Konservatisme akuntansi diharapakan dapat meningkatkan nilai perusahaan, namun hal ini dapat terganggu karena tindakan manajemen laba yang menurunkan kualitas laba tersebut. Padahal, konservatisme akuntansi masih dianggap menjadi perdebatan, dianggap dapat meningkatkan nilai perusahaan dengan didukung oleh 
kualitas laba yang semakin baik. Artinya, ketika perusahaan menerapkan prinsip konservatisme akuntansi dan menghasilkan laba yang mencerminkan kinerja perusahaan sesungguhnya, maka prinsip konservatisme akuntansi tersebut dapat memotivasi investor dalam mengambil keputusan investasi. Meningkatnya investasi yang dilakukan oleh investor mengindikasikan nilai perusahaan di pasar modal meningkat secara tidak langsung melalui kualitas laba perusahaan.

$\mathrm{Ha}_{4}$ : Konservatisme akuntansi (KONS) berpengaruh terhadap nilai perusahaan (NP) melalui kualitas laba (KL).

\section{Metode Penelitian}

\section{Populasi dan Sampel}

Populasi pada penelitian ini adalah perusahaan-perusahaan manufaktur yang sahamnya terdaftar dalam Bursa Efek Indonesia pada tahun 2016-2018. Teknik pengumpulan data yang digunakan adalah teknik observasi dengan pengamatan terhadap data sekunder daftar perusahaan manufaktur dan laporan keuangan yang telah diaudit diperoleh dari www.idx.co.id, Teknik pengambilan sampel yang digunakan dalam penelitian ini adalah nonprobability sampling, yaitu dengan metode purposive sampling. Kriteriakriteria yang dirumuskan oleh peneliti adalah sebagai berikut perusahaan tergolong dalam industri manufaktur yang terdaftar di Bursa Efek Indonesia, perusahaan yang sudah listing sebelum tahun 2016 dan tidak mengalami delisting selama periode penelitian 2016-2018, perusahaan memiliki laporan keuangan yang berakhir pada 31 Desember dan disajikan dalam mata uang rupiah untuk periode 2016-2018, perusahaan tidak mengalami defisiensi ekuitas selama periode penelitian, perusahaan memiliki data yang lengkap untuk penelitian.

\section{Pengukuran Variabel}

Pada penelitian ini, variabel dependennya adalah nilai perusahaan dengan proksi price to book value (PBV). Jika PBV bernilai lebih dari 1, maka mengindikasikan penilaian investor terhadap perusahaan lebih tinggi dibandingkan ekuitas perusahaan (overvalued). Semakin besar PBV, maka semakin mahal harga saham perusahaan. Rumus price to book value seperti yang digunakan oleh Wijaya dan Hasniar (2016) dan Nafiah et al. (2018) ialah sebagai berikut:

$\mathrm{PBV}=\frac{\text { Harga pasar per lembar saham }}{\text { Nilai buku per lembar saham }}$

Variabel independen pada penelitian ini ialah konservatisme akuntansi. proksi yang digunakan untuk mengukur konservatisme akuntansi adalah earnings / accrual measure oleh Givoly dan Hayn (2000) yang digunakan juga oleh Tuwentina dan Wirama (2014), Karlina (2016), serta Mukminah et al. (2018). Rumusnya ialah sebagai berikut:

$\mathrm{C}_{\mathrm{it}}=\frac{\left(\mathrm{NI}_{\mathrm{it}}-\mathrm{CFO}_{\mathrm{it}}\right) \mathrm{x}(-1)}{\mathrm{TA}_{\mathrm{it}}}$

Keterangan:

$\mathrm{C}_{\mathrm{it}}$ : Nilai akrual yang menunjukkan tingkat konservatisme perusahaan $\mathrm{i}$ pada tahun $\mathrm{t}$

$\mathrm{NI}_{\mathrm{it}} \quad$ : Net Income sebelum extraordinary items ditambah depresiasi dan amortisasi dari perusahaan i pada tahun $\mathrm{t}$

$\mathrm{CFO}_{\mathrm{it}}$ : Arus kas operasional perusahaan i pada tahun $\mathrm{t}$

$\mathrm{TA}_{\mathrm{it}}$ : Total aset perusahaan i pada tahun $\mathrm{t}$

Penerapan prinsip konservatisme akuntansi ditandai dengan laba bersih yang lebih rendah dibandingkan arus kas operasional perusahaan (nilai akrual negatif). Namun untuk memudahkan perhitungan maka nilai akrual negatif tersebut akan dikalikan dengan (-1), sehingga dalam penelitian ini nilai akrual positif mengindikasikan penerapan metode akuntansi yang konservatif.

Pada penelitian ini variabel intervening yang digunakan adalah kualitas laba. Proksi yang digunakan adalah discretionary accruals dengan Modified Jones Model yaitu Model Jones (1991) yang 
dimodifikasi oleh Dechow et al. (1995). Semakin kecil discretionary accruals, maka semakin tinggi kualitas laba perusahaan (Siallagan, 2009). Proksi ini digunakan juga pada penelitian Manik (2018), Jonathan dan Machdar (2018), serta Lara et al. (2019). Formula lengkap dari Modifikasi Model Jones ialah sebagai berikut:

1. Total accruals (TA) dihitung dengan rumus:

$$
\mathrm{TA}_{\mathrm{it}}=\mathrm{NI}_{\mathrm{it}}-\mathrm{CFO}_{\mathrm{it}}
$$

2. Total accruals (TA) diestimasi sebagai berikut:

$$
\begin{aligned}
& \frac{\mathrm{TA}_{\mathrm{it}}}{\mathrm{A}_{\mathrm{it}-1}}=\beta_{1}\left(\frac{1}{\mathrm{~A}_{\mathrm{it}-1}}\right)+\beta_{2}\left(\frac{\Delta \mathrm{REV}_{\mathrm{it}}-\Delta \mathrm{REC}_{\mathrm{it}}}{\mathrm{A}_{\mathrm{it}-1}}\right) \\
& +\beta_{3}\left(\frac{\mathrm{PPE}_{\mathrm{it}}}{\mathrm{A}_{\mathrm{it}-1}}\right)+\varepsilon_{\mathrm{it}} \ldots \ldots \ldots \ldots \ldots \ldots . . . . . . . .
\end{aligned}
$$

3. Non-discretionary accruals (NDA) ditentukan dengan rumus:

$$
\begin{aligned}
& \mathrm{NDA}_{\mathrm{it}}=\beta_{1}\left(\frac{1}{\mathrm{~A}_{\mathrm{it}-1}}\right)+\beta_{2}+\left(\frac{\Delta \mathrm{REV}_{\mathrm{it}}-\Delta \mathrm{REC}_{\mathrm{it}}}{\mathrm{A}_{\mathrm{it}-1}}\right) \\
& +\beta_{3}\left(\frac{\mathrm{PPE}_{\mathrm{it}}}{\mathrm{A}_{\mathrm{it}-1}}\right) \quad \ldots \ldots \ldots \ldots \ldots \ldots \ldots \ldots(5)
\end{aligned}
$$

4. Discretionary accruals (DA) sebagai ukuran tinggi rendahnya kualitas laba ditentukan dengan rumus:

$\mathrm{DA}_{\mathrm{it}}=\frac{\mathrm{TA}_{\mathrm{it}}}{\mathrm{A}_{\mathrm{it}-1}}-\mathrm{NDA}_{\mathrm{it}}$

\section{Teknik Analisis Data}

\section{Statistika Deskriptif}

Statistika deskriptif membahas gambaran umum berupa informasi mengenai data yang diperoleh dalam suatu penelitian, antara lain informasi mengenai nilai rata-rata (mean), nilai maksimum, nilai minimum, standar deviasi, sum, dan range dari variabel yang diteliti (Ghozali, 2016:19).

Uji Asumsi Klasik

1. Uji Normalitas

Tujuan uji normalitas ini adalah menguji apakah dalam model regresi tersebut, variabel pengganggu atau residual mempunyai distribusi normal (Ghozali, 2016:154). Jika data berdistribusi normal, maka analisis parametik dapat digunakan. Uji normalitas pada penelitian ini menggunakan One-Sample Kolmogorov-Smirnov Test pada SPSS 22.

2. Uji Autokorelasi

Uji autokorelasi digunakan pada data runtut waktu (time series) yang bertujuan mengetahui apakah model regresi linear tersebut terdapat saling hubungan antara kesalahan pengganggu pada periode $t$ dengan kesalahan pengganggu pada periode t-1. Pengujian autokorelasi menggunakan uji DurbinWatson (DW) pada SPSS 22.

3. Uji Heterokedastisitas

Tujuan uji heteroskedastisitas adaalh menguji apakah terjadi ketidaksamaan variance dari residual dalam satu pengamatan ke pengamatan lain. Jika variance residual satu pengamatan ke pengamatan lain tetap, maka disebut homoskedastisitas, jika variance berbeda disebut heteroskedastisitas. Model regresi yang baik adalah homoskedastisitas (Ghozali, 2016:134). Pengujian heteroskedastisitas menggunakan Uji Park dengan SPSS 22.

4. Uji Multikolinearitas

Uji multikolinearitas dilakukan untuk menguji model regresi linear berganda apakh terjadi korelasi antar variabel independen. Model regresi yang baik adalah jika tidak terjadi korelasi di antara variabel bebas (Ghozali, 2016:103). Pengujian multikolinearitas ini dilakukan dengan perhitungan nilai Tolerance dan Variance Inflation Factor (VIF) pada SPSS 22.

\section{Analisis Regresi Linear}

Metode yang digunakan dalam penelitian ini adalah analisis regresi sederhana dan analisis regresi berganda. Menurut Ghozali (2016:93), analisis regresi adalah analisis mengenai ketergantungan variabel terikat dengan satu atau lebih 
variabel bebas. Pada penelitian ini, analisis regresi dilakukan sebanyak dua kali. Analisis regresi linear untuk penelitian ini dilakukan dengan menggunakan SPSS 22. Berdasarkan pembahasan sebelumnya, telah diuraikan mengenai variabel terikat, variabel bebas, dan variabel intervening sehingga dua model regresi berganda yang terbentuk adalah sebagai berikut:

Model Regresi Pertama:

$\mathrm{NP}=\beta_{0}+\beta_{1} \mathrm{KONS}+\beta_{2} \mathrm{KL}+\varepsilon$

Model Regresi Kedua:

$\mathrm{KL}=\beta_{0}+\beta_{3} \mathrm{KONS}+\varepsilon$

Keterangan:

$\begin{array}{ll}\text { NP } & : \text { Nilai Perusahaan } \\ \text { KONS } & : \text { Konservatisme Akuntansi } \\ \text { KL } & : \text { Kualitas Laba } \\ \beta_{0} & : \text { Konstanta } \\ \beta_{1}, \beta_{2}, \beta_{3} & : \text { Koefisien regresi } \\ \varepsilon & : \text { Error }\end{array}$

Menurut Ghozali (2016:95), ketepatan fungsi regresi dalam menaksir nilai aktual dapat diukur dari Goodness of Fit model penelitian. Pengukuran ini dapat dilakukan melalui uji signifikansi simultan, uji signifikansi parameter individual, dan uji koefisien determinasi.

1. Uji Koefisien Determinasi $\left(\mathrm{R}^{2}\right)$

Koefisien determinasi $\left(\mathrm{R}^{2}\right)$ digunakan untuk mengukur kemampuan variabel independen di dalam model regresi dapat menerangkan atau menjelaskan variasi variabel dependen (Ghozali, 2016:95). Nilai koefisien determinasi adalah antara nol dan satu $\left(0 \leq \mathrm{R}^{2} \leq 1\right)$.

2. Uji Signifikansi Simultan (Uji F)

Uji signifikansi simultan digunakan untuk mengetahui apakah seluruh variabel independen dalam model secara bersama-sama atau simultan mempunyai pengaruh yang signifikan terhadap variabel dependen (Ghozali, 2016:171).

3. Uji Signifikansi Parameter Individual (Uji t)
Uji statistik $\mathrm{t}$ atau uji parsial pada dasarnya digunakan untuk mengetahui apakah masing-masing variabel independen secara individu (parsial) mempunyai pengaruh terhadap variabel dependennya (Ghozali, 2016:171).

\section{Analisis Jalur (Path Analysis)}

Ghozali (2016:237) menyatakan bahwa analisis jalur adalah perluasan dari analisis linear berganda untuk mengestimasi hubungan kausal antar variabel (model kausal) yang ditetapkan sebelumnya berdasarkan teori. Path analysis digunakan untuk menguji pengaruh secara tidak langsung dari suatu model penelitian melalui variabel intervening.

\section{Uji Sobel}

Menurut Ghozali (2016:236), pengujian hipotesis mediasi dapat juga dilakukan dengan prosedur pengujian yang dikembangkan Sobel (1982), dikenal dengan Sobel Test. Uji Sobel menguji dan menghitung kekuatan pengaruh tidak langsung variabel $\mathrm{X}$ (independen) ke $\mathrm{Y}$ (dependen) melalui $\mathrm{Z}$ (intervening). Uji Sobel dengan cara menghitung standar eror pengaruh tidak langsung dengan rumus sebagi berikut:

$\mathrm{Sp} 2 \mathrm{p} 3=\sqrt{\mathrm{p} 3^{2} \mathrm{Sp} 2^{2}+\mathrm{p} 2^{2} \mathrm{Sp} 3^{2}+\mathrm{Sp}^{2} \mathrm{Sp} 3^{2}}$

Keterangan:

Sp2p3: Standar eror pengaruh tidak langsung

p2 : Koefisien jalur variabel intervening dengan variabel dependen

p3 : Koefisien jalur variabel independen dengan variabel intervening

Sp2 : Standar eror koefisien jalur P2

Sp3 : Standar eror koefisien jalur P3

Untuk menguji signifikansi pengaruh tidak langsung, maka perlu dihitung nilai $\mathrm{t}$ dari koefisien p1p2 dengan rumus sebagai berikut:

$\mathrm{t}=\frac{\mathrm{p} 2 \mathrm{p} 3}{\mathrm{Sp} 2 \mathrm{p} 3}$ 
Nilai t hitung dibandingkan dengan t tabel. Jika nilai $\mathrm{t}$ hitung $>\mathrm{t}$ tabel, maka dapat disimpulkan bahwa terjadi pengaruh mediasi (pengaruh tidak langsung antara variabel independen terhadap variabel dependen).

\section{Hasil dan Pembahasan Analisis Deskriptif}

Berdasarkan hasil analisis deskriptif, jumlah sampel penelitian adalah sebanyak 180 sampel. Nilai perusahaan sebagai variabel dependen yang diukur dengan rasio price to book value dalam penelitian ini menunjukkan nilai minimum 0,1803 dan nilai maksimum sebesar 7,0736. Rata-rata nilai perusahaan selama tahun 2016-2018 ialah sebesar 1,6313 dengan standar deviasi 1,2430. Konservatisme akuntansi sebagai variabel independen menunjukkan nilai minimum sebesar $-0,7872$. Sedangkan nilai konservatisme terbesar yaitu 0,3570 mengindikasikan bahwa laba bersih yang dilaporkan lebih rendah dibandingkan besarnya arus kas operasional. Nilai ratarata dari konservatisme akuntansi selama tahun 2016-2018 ialah sebesar -0,0237 dengan standar deviasi 0,1045. Rata-rata yang bernilai negatif tersebut menunjukkan bahwa sebagian besar perusahaan dalam penelitian ini tidak menerapkan prinsip konservatisme akuntansi. Kualitas laba yang diukur dengan besarnya discretionary accruals sebagai variabel intervening dalam penelitian ini menunjukkan nilai minimum 0,000161 yang menunjukkan kualitas laba tertinggi karena nilai discretionary accruals (manajemen laba) rendah. Sedangkan nilai maksimum 1,1706 kualitas laba terendah karena nilai discretionary accruals yang tinggi. Nilai rata-rata kualitas laba selama tahun 2016-2018 sebesar 0,0586 dengan standar deviasi sebesar 0,1159 .

\section{Uji Asumsi Klasik}

\section{Uji Normalitas}

Model persamaan pertama dan kedua masing-masing memiliki Asymp Sig. $0,000<$ alpha 0,05 yang menunjukkan bahwa model persamaan pertama dan kedua memiliki data yang tidak berdistribusi normal. Namun menurut
Bowerman et al. (2014:278) mengenai central limit theorem yaitu distribusi sampel dapat dikatakan normal ketika ukuran sampel lebih besar atau sama dengan 30 sampel. Dalam penelitian ini sampel yang digunakan sebanyak 180 sampel, maka dapat disimpulkan bahwa data penelitian berdistribusi normal.

Tabel 1

Hasil Uji Normalitas

\begin{tabular}{cc}
\hline Model Penelitian & $\begin{array}{c}\text { Asymp Sig. } \\
\text { (2-tailed) }\end{array}$ \\
\hline Model Pertama & 0,000 \\
Model Kedua & 0,000 \\
\hline Sumber: Hasil Pengolahan Peneliti &
\end{tabular}

2. Uji Autokorelasi

Tabel 2

Hasil Uji Autokorelasi

\begin{tabular}{l|c}
\hline \multicolumn{1}{c|}{ Model Penelitian } & Durbin-Watson \\
\hline Model Pertama & 2,485 \\
Model Kedua & 1,958 \\
\hline \multicolumn{2}{l}{ Sumber: Hasil Pengolahan Peneliti }
\end{tabular}

Model persamaan pertama memiliki nilai dl sebesar 1,734 dan nilai du sebesar 1,779. Nilai Durbin-Watson sebesar 2,485 berada di antara (4-dl) dengan $4(2.266<2.485<4)$, maka pada model persamaan pertama terjadi autokorelasi negatif. Gejala autokorelasi ini juga terjadi dalam penelitian Wijayati (2015) dan Nafiah et al. (2018). Autokorelasi dapat terjadi karena data penelitian bukan hanya data time series, melainkan data pooled yang mengandung data cross-sectional (Wijayati, 2015). Model persamaan kedua memiliki nilai dl sebesar 1.745 dan nilai du sebesar 1.767. Nilai DurbinWatson sebesar 1.958 berada di antara nilai du dengan (4-du) yaitu 1.767 < $1.958<2.233$, maka model persamaan kedua ini dapat dinyatakan bahwa tidak terjadi gejala autokorelasi. 
3. Uji Heterokedastisitas

Tabel 3

Hasil Uji Heteroskedastisitas Model Pertama

\begin{tabular}{lc}
\hline \multicolumn{1}{c}{ Variabel } & Sig. \\
\hline $\begin{array}{l}\text { Konservatisme } \\
\text { Akuntansi (KONS) }\end{array}$ & 0,710 \\
Kualitas Laba (KL) & 0,919 \\
\hline Sumber: Hasil Pengolahan Peneliti &
\end{tabular}

Tabel 4

Hasil Uji Heteroskedastisitas Model Kedua

\begin{tabular}{lc}
\hline \multicolumn{1}{c}{ Variabel } & Sig. \\
\hline Konservatisme & 0,984 \\
Akuntansi (KONS) & \\
\hline
\end{tabular}

Sumber: Hasil Pengolahan Peneliti

Seluruh variabel independen pada model persamaan pertama dan kedua memiliki nilai Sig. > alpha 0,05, maka dapat dinyatakan bahwa pada kedua model persamaan tidak terjadi gejala heteroskedastisitas.

4. Uji Multikolinearitas

Tabel 5

Hasil Uji Multikolinearitas

Model Pertama

\begin{tabular}{lcc}
\hline \multicolumn{1}{c}{ Variabel } & Tolerance & VIF \\
\hline $\begin{array}{l}\text { Konservatisme } \\
\text { Akuntansi (KONS) }\end{array}$ & 0,639 & 1,566 \\
Kualitas Laba (KL) & 0,639 & 1,566 \\
\hline
\end{tabular}

Sumber: Hasil Pengolahan Peneliti

Pengujian multikolinearitas hanya dilakukan untuk model persamaan pertama yang merupakan model regresi linear berganda. Variabel konservatisme akuntansi dan kualitas laba memiliki nilai Tolerance 0,639>0,10 dan nilai Variance Inflation Factor (VIF) 1,566 < 10. Maka dapat disimpulkan bahwa model persamaan pertama pada penelitian ini tidak ada gejala multikolinearitas antar variabel independen.

\section{Analisis Regresi Linear}

1. Uji Koefisien Determinasi $\left(\mathrm{R}^{2}\right)$

Model regresi pertama memiliki nilai $\mathrm{R}^{2}$ sebesar 0,036189. Hal ini menunjukkan $3,62 \%$ variabel nilai perusahaan dapat dijelaskan atau dipengaruhi oleh variabel konservatisme akuntansi dan variabel kualitas laba. Sedangkan sisanya 96,38\% menunjukkan bahwa nilai perusahaan dapat dpengaruhi oleh variabel-variabel selain atau di luar model penelitian ini. Model regresi kedua dengan nilai $\mathrm{R}^{2}$ sebesar 0,361265 menunjukkan bahwa $36,13 \%$ variabel kualitas laba dapat dijelaskan atau dipengaruhi oleh variabel konservatisme akuntansi. Sedangkan $\quad 63,87 \%$ menunjukkan bahwa variabel kualitas laba dijelaskan oleh variabel-variabel lain di luar model penelitian.

\section{Uji Signifikansi Simultan (Uji F)}

Tabel 6

Hasil Uji Signifikansi Simultan

\begin{tabular}{lc}
\hline \multicolumn{1}{c}{ Model Regresi } & Sig. \\
\hline Model Pertama & 0,038 \\
Model Kedua & 0,000 \\
\hline \multicolumn{2}{l}{ Sumber: Hasil Pengolahan Peneliti }
\end{tabular}

Model regresi pertama memiliki nilai Sig. $0,038<$ alpha 0,05 , maka model regresi dapat digunakan untuk memprediksi variabel dependen yaitu nilai perusahaan. Dengan kata lain, variabel konservatisme akuntansi dan kualitas laba secara bersama-sama (simultan) berpengaruh terhadap nilai perusahaan. Model regresi kedua memiliki nilai Sig. 0,000 < alpha 0,05, maka model regresi dapat digunakan untuk memprediksi kualitas laba. Kedua model regresi dapat dikatakan sudah fit dan dapat digunakan untuk menguji hipotesis penelitian.

3. Uji Signifikansi Parameter Individual (Uji t)

Pada model regresi pertama, variabel konservatisme akuntansi dengan nilai koefisien beta $-0,519$ dan nilai signifikansi $0,637 / 2=0,319$, menunjukkan nilai Sig. > 
nilai alpha 0,05 , maka dapat disimpulkan bahwa konservatisme akuntansi tidak terbukti berpengaruh terhadap nilai perusahaan.

Tabel 7

Hasil Uji Signifikansi

Parameter Individual Model Pertama

\begin{tabular}{lccc}
\hline $\begin{array}{c}\text { Variabel } \\
\text { Independen }\end{array}$ & $\begin{array}{c}\text { Koefisien } \\
\text { Beta }\end{array}$ & $\begin{array}{c}\text { Sig. } \\
(2- \\
\text { tailed })\end{array}$ & $\begin{array}{c}\text { Sig. } \\
(1- \\
\text { tailed })\end{array}$ \\
\hline KONS & $-0,519$ & 0,637 & 0,319 \\
KL & $-2,286$ & 0,022 & 0,011 \\
\hline
\end{tabular}

Variabel dependen $=$ Nilai Perusahaan (NP)

Koefisien beta konstanta $=1,753$

Sumber: Hasil Pengolahan Peneliti

Variabel kualitas laba dengan nilai signifikansi $\quad 0,022 / 2=0,011$, menunjukkan nilai Sig. < nilai alpha 0,05 , sehingga terbukti bahwa kualitas laba berpengaruh terhadap nilai perusahaan. Kualitas laba yang diproksikan dengan manajemen laba (discretionary accruals) memiliki koefisien beta sebesar -2,286. Artinya semakin tinggi manajemen laba (kualitas laba rendah) maka nilai perusahaan akan semakin rendah atau kualitas laba memiliki hubungan positif dengan nilai perusahaan. Pada model regresi kedua, variabel konservatisme akuntansi memiliki nilai signifikansi $0,000 / 2=$ $0,000<$ nilai alpha 0,05 , maka terbukti bahwa konservatisme akuntansi berpengaruh terhadap kualitas laba. Konservatisme akuntansi yang diukur secara akrual memiliki koefisien beta sebesar $-0,667$. Artinya semakin tinggi tingkat konservatisme akuntansi maka manajemen laba (discretionary accruals) yang dilakukan semakin rendah (kualitas laba semakin tinggi) atau dengan kata lain konservatisme akuntansi memiliki hubungan negatif dengan kualitas laba.
Tabel 8

Hasil Uji Signifikansi

Parameter Individual

Model Kedua

\begin{tabular}{lccc}
\hline $\begin{array}{c}\text { Variabel } \\
\text { Independen }\end{array}$ & $\begin{array}{c}\text { Koefisien } \\
\text { Beta }\end{array}$ & $\begin{array}{c}\text { Sig. } \\
(2- \\
\text { tailed })\end{array}$ & $\begin{array}{c}\text { Sig. } \\
(1- \\
\text { tailed })\end{array}$ \\
\hline KONS & $-0,667$ & 0,000 & 0,000 \\
\multicolumn{4}{l}{} \\
\multicolumn{4}{l}{ Variabel dependen $=$ Kualitas Laba (KL) } \\
Koefisien beta konstanta $=0,043$ \\
Sumber: Hasil Pengolahan Peneliti
\end{tabular}

\section{Analisis Jalur (Path Analysis)}

Pengaruh langsung (direct effect), pengaruh tidak langsung (indirect effect), pengaruh total (total effect) untuk model analisis jalur sebagai berikut:

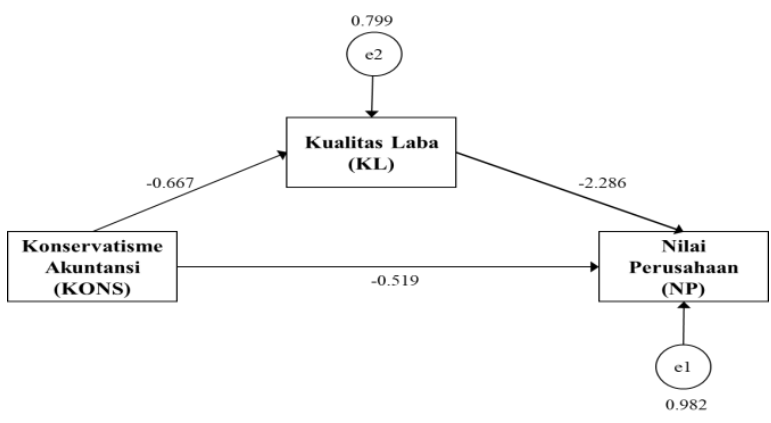

Gambar 1

Model Analisis Jalur Penelitian

Sumber: Hasil Pengolahan Penelitian

Pengaruh langsung

KONS ke NP $=-0,519$

Pengaruh tidak langsung

KONS ke KL ke NP $(-2,286$ x $(-0,667)$

Pengaruh total

$$
=\underline{1,525}+
$$

(korelasi KONS ke NP) = $\quad=1,006$

\section{Uji Sobel}

Melalui analisis jalur diketahui pengaruh mediasi (pengaruh tidak langsung) yang ditunjukkan oleh perkalian P2 dengan P3 menghasilkan koefisien sebesar 1,525. Untuk mengetahui signifikan atau tidaknya koefisien 1,525 tersebut dapat diuji melalui uji Sobel dengan menghitung standar eror dari koefisien pengaruh mediasi sebagai berikut: 
Sp2p3 =

$$
\sqrt{\begin{array}{c}
(-0,667)^{2}(0,990)^{2}+(-2,286)^{2}(0,066)^{2} \\
+(0,990)^{2}(0,066)^{2}
\end{array}}
$$

Sp2p3 $=0,680491$

Selanjutnya, berdasarkan hasil standar eror tersebut dapat dihitung nilai $\mathrm{t}$ statistik pengaruh mediasi sebagai berikut:

$$
t=\frac{1,525}{0,680491}=2,241
$$

Nilai t hitung sebesar 2,241 lebih besar dari nilai t tabel dengan tingkat signifikansi 0,05 yaitu 1,96, maka dapat disimpulkan bahwa koefisien mediasi 1,525 terbukti signifikan. Dengan kata lain, terdapat pengaruh tidak langsung antara konservatisme akuntansi terhadap nilai perusahaan melalui kualitas laba. Berdasarkan hasil uji maka kualitas laba dapat memediasi secara partial. Hal ini dapat diketahui bahwa konservatisme akuntansi mempengaruhi secara tidak langusung terhadap nilai perusahaan melalui kualitas laba, dimana nilai koefisien betanya sebesar 1,525.

\section{Pengaruh Konservatisme Terhadap Nilai Perusahaan}

Akuntansi

Hasil pengujian menunjukkan bahwa konservatisme akuntansi tidak terbukti memiliki pengaruh terhadap nilai perusahaan. Hal ini menunjukkan adanya faktor lain yang menjadi pertimbangan investor dalam menilai perusahaan. Investor tidak melihat konservatisme akuntansi yang diterapkan perusahaan sehingga harga pasar saham tidak meningkat dan mengakibatkan prinsip konservatisme akuntansi tersebut tidak memengaruhi penilaian investor terhadap perusahaan. Pemilihan dan prinsip konservatisme yang diterapkan dapat mengakibatkan adanya pelaporan laba atau aktiva yang menjadi lebih rendah serta melaporkan utang yang menjadi lebih tinggi. Perusahaan besar mempunyai sedikit motivasi untuk melakukan manajemen laba karena perusahaan yang mempunyai aset besar akan memperoleh tekanan kuat untuk menyajikan laporan keuangan yang berkualitas dan dipercaya. Hal ini menyebabkan perusahaan besar cenderungan lebih kecil melakukan tindakan manajemen laba dibandingkan perusahaan kecil. Dari 180 sampel, perusahaan-perusahaan cenderung tidak tidak menerapkan konservatisme. Perusahaan yang menerapkan konservatisme akuntansi hanya diterapkan sebesar $34.44 \%$ (62 sampel), sedangkan sisanya $65.56 \%$ (118 sampel) tidak menerapkan konservatisme akuntansi. Hasil penelitian ini sejalan dengan penelitian sebelumnya yaitu penelitian Yenti dan Syofyan (2013) yang menyatakan bahwa konservatisme yang dihitung dengan earnings / accrual measure tidak mempengaruhi nilai perusahaan di mata investor karena sebagian besar perusahaan manufaktur tidak menerapkan konservatisme secara konsisten. Hasil yang serupa juga diperoleh dari penelitian Jusny (2014) bahwa konservatisne akuntansi tidak berpengaruh signifikan terhadap nilai perusahaan.

\section{Pengaruh Kualitas Laba Terhadap Nilai Perusahaan}

Pengujian yang telah dilakukan menunjukkan bahwa kualitas laba dapat memengaruhi nilai perusahaan. Nilai koefisien beta yang negatif menunjukkan hubungan kualitas laba yang diproksikan dengan discretionary accruals dengan nilai perusahaan yang berlawanan. Rendahya nilai discretionary accruals mengindikasikan bahwa kualitas laba perusahaan semakin baik, sehingga investor menilai perusahaan dengan nilai yang lebih tinggi. Kualitas laba yang baik dianggap sebagai good news bagi investor. Laba yang mengandung unsur discretionary accruals yang rendah mengindikasikan bahwa pihak manajemen perusahaan mampu memberikan sinyal yang terpercaya (credible signal) kepada pihak eksternal, sehingga sinyal tersebut mampu mengurangi asimetri informasi yang biasanya dapat menimbulkan konflik keagenan. Ketika manajer melakukan manajemen laba, maka pemegang saham selaku agen telah 
dirugikan karena beban yang dikeluarkan meningkat yaitu beban bonus kepada manajer. Selain itu, manajemen laba akan berpotensi untuk merusak reputasi perusahaan di pasar modal. Penelitian ini sejalan dengan penelitian Istia'adah (2015) dan penelitian Rahayu dan Sari (2018) yang menyatakan bahwa kualitas laba yang tinggi, yaitu dengan nilai discretionary accruals yang rendah, akan direspon positif oleh pasar sehingga nilai suatu perusahaan akan semakin tinggi.

\section{Pengaruh Konservatisme Akuntansi Terhadap Kualitas Laba}

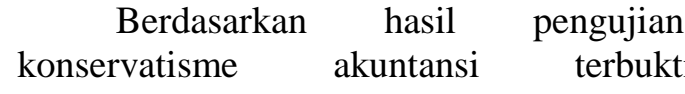
berpengaruh signifikan terhadap kualitas laba. Nilai koefisien beta yang negatif menunjukkan bahwa semakin tinggi konservatisme akuntansi, maka manajemen laba dalam perusahaan akan semakin rendah. Hal ini sesuai dengan konsep di mana konservatisme akuntansi dapat berperan dalam konflik keagenan untuk meminimalisasi tindakan oportunistik yang dilakukan oleh manajer. Tindakan oportunisnik tersebut merupakan manajemen laba yaitu tindakan memanipulasi laba yang dapat menurunkan kualitas laba perusahaan. Manajemen laba yang rendah mengindikasikan bahwa kualitas laba yang dilaporkan perusahaan baik tanpa mengandung unsur discretionary accruals tinggi. Perusahaan dapat memilih metode akuntansi yang akan digunakan, tidap perlu harus sama dengan eprusahaan yang lain. Perusahaan diberikan kebebasan untuk memilih metode yang sesuai dengan kondisi, jenis dan tujuan perusahaan. Misalnya dengan menerapkan metode akuntansi yang konservatif dalam pelaporan keuangan agar kecenderungan manajer untuk melakukan tindakan yang oportunis berupa manajemen laba dapat dicegah sehingga kualitas laba perusahaan dapat meningkat dan konflik keagenan juga dapat diminimalisasi. Hasil penelitian ini mendukung penelitian Sugianto dan Sjarief (2018) yang menyatakan bahwa pasar merespon laporan keuangan yang konservatif sebagai good news karena kualitas laba yang dilaporkan perusahaan lebih baik.

\section{Pengaruh Konservatisme Akuntansi Terhadap Nilai Perusahaan Melalui Kualitas Laba}

Pengujian hipotesis pertama tidak memiliki bukti bahwa konservatisme akuntansi dapat memengaruhi nilai perusahaan secara langsung. Namun, hasil pengujian hipotesis keempat menunjukkan bahwa konservatisme akuntansi mampu memengaruhi nilai perusahaan secara tidak langsung yaitu melalui kualitas laba. Investor meragukan penerapan metode akuntansi yang konservatif dalam menilai suatu perusahaan. Namun, ketika konservatisme akuntansi tersebut disertai dengan laba yang berkualitas, dimana laba tersebut mampu menjadi good news bagi pasar, maka nilai perusahaan dapat meningkat. Hasil penelitian ini sesuai dengan pernyataan Asri dan Habbe (2017) dalam penelitiannya bahwa pihak manajemen yang menerapkan prinsip kehati-hatian dalam melaporkan laba perusahaan mampu memberikan sinyal yang akan direspon positif oleh investor. Menurut investor, implementasi dari metode akuntansi yang konservatif akan menghasilkan laba yang berkualitas, sehingga investor akan menilai perusahaan dengan nilai yang lebih tinggi.

\section{Simpulan}

Berdasarkan hasil pengujian yang telah dilakukan dalam penelitian ini, dapat disimpulkan bahwa konservatisme akuntansi terbukti tidak berpengaruh secara signifikan terhadap nilai perusahaan. Kualitas laba terbukti berpengaruh positif terhadap nilai perusahaan. Konservatisme akuntansi terbukti berpengaruh positif terhadap kualitas laba. Konservatisme akuntansi terbukti berpengaruh signifikan secara tidak langsung terhadap nilai perusahaan melalui kualitas laba.

Berdasarkan salah satu hasil penelitian yaitu bahwa konservatisme akuntansi tidak terbukti memiliki pengaruh terhadap nilai perusahaan, maka saran untuk peneliti selanjutnya adalah 
menggunakan kualitas laba sebagai variabel moderasi. Hal ini dimaksudkan untuk meneliti apakah kualitas laba dapat memperkuat atau memperlemah pengaruh konservatisme akuntansi terhadap nilai perusahaan.

\section{Daftar Pustaka}

Agustia, Y. P., \& Suryani, E. (2018), Pengaruh Ukuran Perusahaan, Umur Perusahaan, Leverage, Dan Profitabilitas Terhadap Manajemen Laba, Jurnal ASET (Akuntansi Riset), Vol. 10, no. 1, p.63-74.

Akerlof, G. A. (1970), The Market for "Lemons": Quality Uncertainty and the Market Mechanism, The Quarterly Journal of Economics.

Alim, S. (2009), Manajemen Laba dengan Motivasi Pajak pada Badan Usaha Manufaktur di Indonesia, Jurnal Keuangan Dan Perbankan, Vol. 13, no. 3 .

An, Y. (2017), Measuring Earnings Quality over Time. International Journal of Economics and Financial Issues, Vol. 7, no. 3, p.82-87.

Andreas, H. H., Ardeni, A., \& Nugroho, P. I. (2017), Konservatisme Akuntansi di Indonesia, Jurnal Ekonomi Dan Bisnis, Vol. 20, no. 1.

Anita, A., \& Yulianto, A. (2016), Pengaruh Kepemilikan Manajerial dan Kebijakan Dividen terhadap Nilai Perusahaan, Management Analysis Journal Universitas Negeri Semarang, Vol. 5, no. 1.

Asri, M., \& Habbe, A. H. (2017), Accounting Conservatism and Earning Quality, SSRN Electronic Journal.

Augustine, S. E. (2016), Pengaruh Konservatisme Akuntansi terhadap Nilai Perusahaan dan Good Corporate Governance sebagai Variabel Moderasi, Artikel Ilmiah STIE Perbanas Surabaya.

Awuy, V. P., Sayekti, Y., \& Purnamawati, I. (2016), Pengaruh Pengungkapan Corporate Social Responsibility
(CSR) Terhadap Earnings Response Coefficient ( ERC ), Jurnal Akuntansi Dan Keuangan, Vol. 18, no. 1, p.1526.

Ayuningtyas, D. (2019), “Kinerja KAEF \& INAF Kompak Loyo, Holding Farmasi Jadi Solusi?", CNBC Indonesia, diakses 6 Oktober 2019, https://www.cnbcindonesia.com/mar ket/20190918110842-17-100278/

kiner ja-kaef-inaf-kompak-loyooldingfarmasi-jadi-solusi/2

Ball, R., \& Shivakumar, L. (2005), The Role of Accruals in Asymmetrically Timely Gain and Loss Recognition, Journal of Accounting Research.

Basu, S. (1997), The conservatism principle and the asymmetric timeliness of earnings, Journal of Accounting and Economics.

Basuki, \& Siregar, I. G. (2019), Pengaruh Good Corporate Governance Dan Prudent Akuntansi Terhadap Nilai Perusahaan Pada Perusahaan Manufaktur 2014-2017, Seminar Nasional Dan The 2nd Call of Syariah Paper.

Beaver, W. H., \& Ryan, S. G. (2000), Biases and Lags in Book Value and Their Effects on the Ability of the Book-to-Market Ratio to Predict Book Return on Equity, Journal of Accounting Research.

Belkaoui, A. R. (1999), Earnings Measurement, Determination, Management, and Usefulness: an empirical approach, Edisi 1, London: Greenwood Publishing Group Inc.

Bellovary, J. L., Giacomino, D. E., \& Akers, M. D. (2005), Earnings Quality: It's Time to Measure and Report, The CPA Journal, Vol. 75, no. 11.

Bowerman, B. L., O'Connell, R. T., \& Murphree, E. S. (2014), Business Statistic in Practice, Edisi 7, New York: Mc Graw Hill Irwin.

Brealey, R. A., Myers, S. C., \& Marcus, A. J. (2018), Fundamentals of Corporate Finance, Edisi 9, New York: Mc Graw Hill Education.

Brigham, E. F., \& Houston, J. F. (2013), Fundamentals of Financial 
Management, Edisi 8, Mason: South Western Cengage Learning.

Budianto, W., \& Payamta, P. (2014), Pengaruh Kepemilikan Manajerial Terhadap Nilai Perusahaan Dengan Kebijakan Dividen Sebagai Variabel Moderasi, Assets: Jurnal Akuntansi Dan Pendidikan, Vol. 3, no. 1.

Cooper, D. R., \& Schindler, P. S. (2014). Business Research Methods, Edisi 12, New York: Mc Graw Hill Irwin.

DeAngelo, L. E. (1986), Accounting Numbers as Market Valuation Substitutes: A Study of Management Buyouts of Public Stockholders, The Accounting Review.

Dechow, P. M., \& Dichev, I. D. (2002), The quality of accruals and earnings: The role of accrual estimation errors, The Accounting Review.

Dechow, P. M., \& Schrand, C. M. (2004), Earnings Quality, The Research Foundation of CFA Institute.

Dechow, P. M., \& Skinner, D. J. (2000), Earnings management: Reconciling the views of accounting academics, practitioners, and regulators, Accounting Horizons.

Dechow, P. M., \& Sloan, R. G. (1991), Executive incentives and the horizon problem. An empirical investigation, Journal of Accounting and Economics.

Dechow, P. M., Sloan, R. G., \& Sweeney, A. P. (1995), Detecting Earnings Management. The Accounting Review, Vol. 70, no. 2, p.73-105.

Deva, B., \& Machdar, N. M. (2017), Pengaruh Manajemen Laba Akrual dan Manajemen Laba Riil Terhadap Nilai Perusahaan dengan Good Corporate Governance sebagai Variabel Moderating, The First National Conference on Business \& Management (NCBM) 2017.

Deviyanti, D. A. (2012), Skripsi: Analisis Faktor-Faktor yang Mempengaruhi Penerapan Konservatisme Akuntansi Dalam Akuntansi, Fakultas Ekonomi dan Bisnis Universitas Diponegoro.

Dewi, A. K., \& Devie. (2017), Pengaruh Earnings Quality terhadap Firm Value dengan Financial
Performance sebagai variabel intervening pada perusahaan yang terdaftar pada perusahaan $L Q 45$, Business Accounting Review, Vol. 5, no. 2.

Dewi, I. G. A. R. P., Yadnyana, I. K., \& Sudana, I. P. (2016), Pengaruh Profitabilitas dan Ukuran Perusahaan Terhadap Ketepatwaktuan Penyampaian Laporan Keuangan dan Implikasinya pada Earning Response Coefficient, E-Jurnal Ekonomi Dan Bisnis Universitas Udayana, Vol. 9, no. 5, p.3031-3056.

Ewert, R., \& Wagenhofer, A. (2012), Earnings management, Conservatism, and Earnings Quality, Foundations and Trends in Accounting, Vol. 6, no. 2.

Fatimah, Mardani, R. M., \& Wahono, B. (2019), Pengaruh Good Corporate Governance Terhadap Nilai Perusahaan dengan Kinerja Keuangan Sebagai Variabel Intervening, E-Jurnal Riset Manajemen Prodi Manajemen.

Fauzi, A. K., Pituringsih, E., \& Inapty, B. A. (2015), Determinan yang Mempengaruhi Kualitas Laba Pada Perusahaan Manufaktur di Indonesia (Analisis Sebelum dan Sesudah Adopsi IFRS), Jurnal Riset Akuntansi Mercu Buana ( JRAMB ), Vol. 1, no. 2.

Feltham, G. A., \& Ohlson, J. A. (1995), Valuation and Clean Surplus Accounting for Operating and Financial Activities, Contemporary Accounting Research.

Francis, B., Hasan, I., \& Wu, Q. (2013), The Benefits of Conservative Accounting to Shareholder, Accounting Horizons, Vol. 27, no. 2, p.319-346.

Francis, J., LaFond, R., Olsson, P., \& Schipper, K. (2002), The Market Pricing of Earnings Quality, SSRN Electronic Journal.

Ghozali, I. (2016), Aplikasi Analisis Multivariete dengan program IBM SPSS 23, Edisi 8, Semarang: Badan Penerbit Universitas Diponegoro. 
Gitman, L. J., \& Zutter, C. J. (2015), Principles of Managerial Finance, The British Accounting Review.

Givoly, D., \& Hayn, C. K. (2000), The Changing time-series properties of earning, cash flows and accrual: Has financial reporting become more conservative?, Journal of Accounting and Economics, Vol. 29, p.287-320.

Givoly, D., Hayn, C. K., \& Katz, S. P. (2010), Does Public Ownership of Equity Improve Earnings Quality?, The Accounting Review American Accounting Association. Vol. 85, no. 1, p.195-225

Gunawan, I. K., Darmawan, N. A. S., \& Purnamawati, I. G. A. (2015), Pengaruh Ukuran Perusahaan, Profitabilitas, dan Leverage Terhadap Manajemen Laba Pada Perusahaan Manufaktur yang Terdaftar di Bursa Efek Indonesia (BEI), Jurnal Akuntansi Program S1 Universitas Pendidikan Ganesha, Vol. 3, no. 1.

Hartono, R. A., \& Sabeni, A. (2014), Pengaruh Konservatisme Akuntansi Terhadap Nilai Perusahaan Pada Krisis Keuangan Tahun 2008, Vol. 3.

Haque, A., Mughal, A., \& Zahid, Z. (2016), Earning Management and the Role of Accounting Conservatism at Firm Level, International Journal of Economics and Finance, Vol. 8, no. 2, p.197-205.

Healy, P. M. (1985), The effect of bonus schemes on accounting decisions. Journal of Accounting and Economics, Vol. 7, p.85-107.

Healy, P. M., \& Wahlen, J. M. (1999), A review of the earnings management literature and its implications for standard setting, Accounting Horizons.

Isti'adah, U. (2015), Faktor-Faktor yang Mempengaruhi Nilai Perusahaan Pada Perusahaan Manufaktur, Jurnal Bisnis Dan Akuntansi, Vol. 9, no. 2.

Jensen, M. C., \& Meckling, W. H. (1976), Theory of the Firm: Managerial, Journal of Financial Economics.

Jogiyanto. (2017), Teori Portofolio dan Analisis Investasi, Edisi 11,
Yogyakarta: BPFE.

Jonathan, J., \& Machdar, N. M. (2018), Pengaruh Kualitas Laba Terhadap Nilai Perusahaan Dengan Reaksi Pasar Sebagai Variabel Intervening, Jurnal Riset Manajemen Dan Bisnis (JRMB) Fakultas Ekonomi UNIAT, Vol. 3, no. 1, p.67-76.

Jones, J. J. (1991), Earnings Management During Import Relief Investigations, Journal of Accounting Research.

Jusny, F. (2014), Pengaruh Konservatisme Akuntansi Terhadap Nilai Perusahaan Dimoderasi Oleh Good Corporate Governance, Jurnal Audit Dan Akuntansi Fakultas Ekonomi Universitas Tanjungpura, Vol. 3, no. 4.

Karlina, E. Y. (2016), Analisis FaktorFaktor yang Mempengaruhi Kualitas Laba Perusahaan pada Industri Barang dan Konsumsi yang Terdaftar di Bursa Efek Indonesia, STIE Perbanas Surabaya.

Laia, Gusti Rahmat Yanti \& Delori Nancy Meyla (2020), Pengaruh Akuntansi Konservatisme Terhadap Relevansi Nilai Laporan Keyangan Dengan Kualitas Laba Sebagai Variabel Moderasi, Pareso Jurnal (Jurnal Pengembangan Ilmu Akuntansi \& Keuangan) Vol. 2 No. 3 (2020):

Lafond, R., \& Roychowdhury, S. (2008), Managerial ownership and accounting conservatism, Journal of Accounting Research.

Lara, J. M. G., Osma, B. G., \& Penalva, F. (2019), Accounting Conservatism and the Limits to Earnings Management, SSRN Electronic Journal.

Lestari, N. B., Khafid, M., \& Anisyukurilla, I. (2014), Pengaruh Good Corporate Governance Terhadap Nilai Perusahaan Dengan Kualitas Laba Sebagai Variabel Intervening, Accounting Analysis Journal, Vol. 3, no. 1, p.34-43.

Lestari, S. P., Paramita, P. D., \& Pranaditya, A. (2018), Pengaruh Ukuran Perusahaan, Profitabilitas, dan Likuiditas Terhadap Nilai Perusahaan dengan Manajemen 
Laba Sebagai Variabel Intervening, Journal Of Accounting.

Li, F. (2011), Earnings Quality and Earnings Management, University of Wollongong Research Online University.

Li, H. (2019), Conservatism, Earnings Management and $R \& D$ Capitalization, International Journal of Financial Research, Vol. 10, No. 2.

Machdar, N. M., Manurung, A. H., \& Murwaningsari, E. (2017), The Effects of Earnings Quality, Conservatism, and Real Earnings Management on the Company's Performance and Information Asymmetry as a Moderating Variable, International Journal of Economics and Financial Issues, Vol. 7, no. 2, p.309-318.

Madyakusumawati, S., \& Yulius, A. (2017), Menilai Kualitas Laba Perusahaan Melalui Instrumen Analisa Du Pont, Jurnal Ekonomi Universitas Bunda Mulia, Vol. 2, no. 1), p.75-94.

Makhdalena. (2009), Pengaruh Komisaris Independen Terhadap Internal Control, Jurnal Pendidikan Ekonomi Dan Bisnis, Vol. 1, no. 1, p.58-65.

Mandey, S. R., Pangemanan, S., \& Pangerapan, S. (2017), Analisis Pengaruh Insider Ownership, Leverage, Dan Profitabilitas Terhadap Nilai Perusahaan Pada Sektor Perusahaan Manufaktur Di Bursa Efek Indonesia Periode Tahun 2013-2015, Jurnal Riset Ekonomi, Manajemen, Bisnis Dan Akuntansi, Vol. 5, no. 2.

Manik, T. (2018), Pengaruh Manajemen Laba dan Konservatisme Akuntansi Terhadap Nilai Perusahaan dengan Kinerja Perusahaan Sebagai Variabel Pemoderasi, Vol. 2, no. 1, p.1-14.

Mawati, E. R., Hardiningsih, P., \& Srimindarti, C. (2017), Corporate Governance Memoderasi Earnings Management dan Profitabilitas terhadap Nilai Perusahaan, Jurnal Akuntansi Prosiding Seminar
Nasional UNISBANK 3 (Sendi_U 3), p.519-528.

Meilany dan Wahyu Nurul Hidayanti (2020), Pengaruh Prudence dan Perencanaan Pajak Terhadap Nilai Perusahaan Dengan Profitabilitas Sebagai Pemoderasi, Jurnal Disrupsi Bisnis, Vol. 3, No. 3, (67-88)

Monahan, S. J. (1999), Conservatism, Growth and the Role of Accounting Numbers in the Equity Valuation Process, SSRN Electronic Journal.

Mukminah, Maslichah, \& Mawardi, M. C. (2018), Pengaruh Konservatisme Akuntansi terhadap Penilaian Ekuitas Perusahaan dengan Good Corporate Governance sebagai Variabel Pemoderasi, E-JRA Fakultas Ekonomi dan Bisnis Universitas Islam Malang. E-JRA Vol. 7, no. 4, p.48-61.

Murhadi, W. (2009), Analisis Saham Pendekatan Fundamental, Jakarta: PT Indeks.

Nafiah, Fathoni, A., \& Paramita, P. D. (2018), The Effect of Profit Management on Company Values with Firm Size and Audit Quality As Moderating Variables, Jurnal Ekonomi Universitas Pandanaran Semarang.

Ningsih, P. P., \& Indarti, I. (2012). Pengaruh Keputusan Investasi, Keputusan Pendanaan, dan Kebijakan Dividen Terhadap Nilai Perusahaan (Studi Kasus Pada Perusahaan Manufaktur Yang Terdaftar Di Bursa Efek Indonesia Periode 2007-2009). Journal of Financial and Banking, Vol. 1, no. 1, p.1-23.

Nurbayani. (2017), Pengaruh Earnings Management terhadap Earnings Quality dengan Adopsi IFRS sebagai Variabel Moderasi, Jurnal Ilmiah Akuntansi Peradaban, Vol. 3, no. 1, p.117-133.

Oktaviani, R. N., Nur, E., \& Ratnawati, V. (2015), Pengaruh Good Corporate Governance Terhadap Kualitas Laba Dengan Manajemen Laba Sebagai Variabel Intervening. Jurnal SOROT LPPM Universitas Riau, Vol. 10, no. 
1, p.36-53.

Pasaribu, R. B. F., Kowanda, D., \& Widyastuty, E. D. (2016), Pengaruh Konservatisme Akuntansi, Kepemilikan Manajerial, Kebijakan Dividen, Ukuran Perusahaan, Leverage, Price Earning Ratio, Price To Book Value, dan Earning Per Share Terhadap Manajemen Laba. Jurnal Ekonomi Dan Bisnis, Vol. 10, no. 2.

Penman, S. H., \& Zhang, X. J. (2002), Accounting Conservatism, the Quality of Earnings, and Stock Returns, The Accounting Review, Vol. 77, no. 2, p.237-264.

Priantinah, D. (2016), Perspektif Oportunistik dan Efisien dalam Fenomena Manajemen Laba. Jurnal Pendidikan Akuntansi Indonesia, Vol. 14, no. 2.

Purwantini, V. T., \& Supriyono. (2018), Analisa Faktor yang Berpengaruh Terhadap Nilai Perusahaan dengan Kuaklitas Laba Sebagai Variable Intervening Pada Perusahaan Manufaktur, Jurnal Ekonomi dan Perbankan, Vol. 3, no. 2.

Rahayu, M., \& Sari, B. (2018), FaktorFaktor Yang Mempengaruhi Nilai Perusahaan, Jurnal Analisis Bisnis Ekonomi, Vol. 16, no. 1.

Rahmawati, W. (2019a), "Kinerja saham yang baru bergabung ke indeks LQ45 belum tentu baik", Investasi Kontan, diakses 3 Oktober 2019,https://investasi.kontan.co.id/ne ws/kinerja-saham-yang-barubergabung-ke-indeks-lq45belumtentu-baik

Rizkiadi dan Vinola Herawaty (2020), Pengaruh Prudent Akuntansi, Profitabilitas, Leverage, Dan Ukuran Terhadap Nilai Perusahaan Yang Dimoderasi Oleh Good Corporate Governance, Prosiding Seminar Nasional Pakar ke 3 Tahun 2020

Rahmawati, W. (2019b), "Harga saham Astra International (ASII) turun 5,65\% pada Agustus, ini kata analis", Investasi Kontan, diakses 26 September 2019 , https://investasi.kontan.co.id/news/ harga-saham-astra-international-asiiturun-565- pada-agustus-ini-

kata-analis

Rustan, Said, D., \& Rura, Y. (2014), Pengaruh Struktur Kepemilikan terhadap Nilai Perusahaan: Kualitas Laba dan Kebijakan Hutang sebagai Variabel Intervening, Jurnal Analisis Fakultas Ekonomi Universitas Hasanuddin, Vol. 3, no. 1.

Ruwanti, S. (2016), Pengaruh Konservatisme Akuntansi pada Manajemen Laba. Journal of Accounting and Economics, Vol. 6, no. 1, p.1-12.

Sarafina, S., \& Saifi, M. (2017), Pengaruh Good Corporate Governance terhadap Kinerja Keuangan dan Nilai Perusahaan (Studi pada Badan Usaha Milik Negara Yang Terdaftar Di Bursa Efek Indonesia Tahun 2010-2013). Jurnal Administrasi Bisnis, Vol. 50, no. 3, p.108-117.

Sari, M. L. (2019), Pengaruh Konservatisme Akuntansi Dan Good Corporate Governance Terhadap Earnings Management. Jurnal Akuntansi Unesa, Vol. 7,no. 1, p.125.

Savitri, E. (2016), Konservatisme Akuntansi: Cara Pengukuran, Tinjauan Empiris dan Faktor-Faktor yang Mempengaruhinya. Konservatisme Akuntansi: Cara Pengukuran, Tinjauan Empiris dan Faktor-Faktor yang Mempengaruhinya, Edisi 1, Yogyakarta: Pustaka Sahila.

Scott, W. R. (2015), Financial Accounting Theory, Edisi 7, Toronto: Pearson Canada Inc.

Sepang, S. J. A. (2014), Analisis Kinerja Dalam Peningkatan Laba PT Jasa Raharja (Persero), Jurnal Akuntansi $\&$ Bisnis.

Setijaningsih, H. T. (2012), Teori Akuntansi Positif dan Konsekuensi Ekonomi, Jurnal Akuntansi Fakultas Ekonomi Universitas Tarumanegara Jakarta, Vol.16, no. 3, p.427-438.

Siallagan, H. (2009), Pengaruh Kualitas Laba Terhadap Nilai Perusahaan. JURNAl

AKUNTANSI 
KONTEMPORER, Vol. 1, no.1, p.21-32.

Siallagan, H., \& Machfoedz, M. (2006), Mekanisme Corporate Governance, Kualitas Laba dan Nilai Perusahaan. Simposium Nasional Akuntansi 9 Padang, p.1-23.

Simorangkir, R. T. M. C. (2019), Factors Influence Firm Value. European Journal of Business and Management, Vol. 11, no. 6, p.68-76.

Sitio, D., Ar, M. D., \& Husaini, A. (2013), Pengaruh Variabel Fundamental Terhadap Harga Saham, Jurnal Fakultas Ilmu Administrasi Universitas Brawijaya, Vol. 13, no. 3.

Sobel, M. E. (1982), Asymptotic Confidence Intervals for Indirect Effects in Structural Equation Models. Sociological Methodology, Vol. 13, p.290-312.

Soraya, I., \& Harto, P. (2014), Pengaruh Konservatisma Akuntansi Terhadap Manajemen Laba Dengan Kepemilikan Manajerial Sebagai Variabel Pemoderasi, Diponegoro Journal Of Accounting, Vol. 3, no. 3 .

Spence, M. (1973), Job Market Signaling, The Quarterly Journal of Economics, Vol. 87, no. 3 .

Sriyani. (2017), Skripsi: Pengaruh Konservatisme Akuntansi Terhadap Nilai Perusahaan dengan Komite Audit dan Kepemilikan Institusional Sebagai Variabel Moderasi, Fakultas Ekonomi dan Bisnis Universitas Lampung.

Sugianto, S., \& Sjarief, J. (2018), Analisis Pengaruh Kepemilikan Manajerial, Proporsi Dewan Komisaris Independen, dan Konservatisme Akuntansi Terhadap Kualitas Laba Serta Pengaruhnya Terhadap Nilai Perusahaan. Jurnal Akuntansi Universitas Atma Jaya, Vol. 12, no. 1.

Sugiyono. (2016), Metode Penelitian Pendekatan Kuantitatif Kualitatif dan $R \& D$, Bandung: Alfabeta.

Sumarah, D. R. (2018), Analisis Kinerja Keuangan Perusahaan, Nilai Perusahaan, dan Harga Saham
Perusahaan yang Melakukan Merger dan Akuisisi Tahun 2010-2014. Journal of Chemical Information and Modeling, Vol. 53, no. 9.

Suyono, E. (2017), Bebagai Model Pengukuran Earnings Management: Mana yang Paling Akurat, Sustainable Competitive Advantage7 (Sca-7) FEB UNSOED, p.303-324. Theophillus, A., \& Akintoye, R. (2018), Earnings Quality and Firms Financial Performance: A Missing Link in Thelisted Firms in Nigeria. International Journal of Accounting \& Finance, Vol. 7, no. 2, p.32-54.

Tuwentina, P., \& Wirama, D. (2014), Pengaruh Konservatisme Akuntansi dan Good Corporate Governance pada Kualitas Laba. E-Jurnal Akuntansi, Vol. 8, no. 2, p.185-201.

Wang, M. (2013), The Study of Accounting Conservatism after the Promulgation of New Accounting Standards for Enterprises - Based on the Evidence in China's Capital Market. International Business Research, Vol. 6, no. 3 .

Watts, R.L, \& Zimmerman, J. (1986), Positive Accounting Theory. New Jersey: Prentice Hall.

Watts, Ross L. (2003), Conservatism in accounting part I: Explanations and implications, Accounting Horizons.

Wijaya, A. H. C., \& Hasniar, N. (2016), Pengaruh Konservatisma Akuntansi terhadap Nilai Ekuitas Perusahaan dengan Good Corporate Governance sebagai Variabel Moderasi, Vol. 11, no. 2, p.1-15.

Wijayati, F. L. (2015), Analisis Pengaruh Kepemilikan Manajerial, Kepemilikan Institusional, Ukuran Dewan Direksi, dan Ukuran Dewan Komisaris Terhadap Biaya Keagenan, Jurnal EBBANK, Vol. 6, no. 2, p.1-16.

Winarto, Y. (2019), "Investor AISA: Kasus AISA adalah skandal dalam pasar modal Indonesia", Investasi Kontan, diakses 27 Septermber 2019, https://investasi.kontan.co.id/news/i nvestor-aisa-kasus-aisa-adalah-

skandal-dalam- pasar-modal-indonesia 
Wolk, H. I., Dodd, J. L., \& Rozycki, J. J. (2017), Accounting Theory: Conceptual Issues in a Political and Economic Environment, Los Angeles: Sage Publications Inc.

Wulanda, M., \& Aziza, N. (2019), Pengaruh Corporate Governance Terhadap Nilai Perusahaan dan Manajemen Laba Sebagai Variabel Intervening Pada Perusahaan Manufaktur Go Public di Indonesia, AKTSAR: Jurnal Akuntansi Syariah, Vol. 2, no. 1.

Yenti, Y. E., \& Syofyan, E. (2013), Penilaian Ekuitas Dengan Good Governance Sebagai Variabel Pemoderasi, Jurnal Wahana Riset Akuntansi, Vol. 1, no. 2, p.201-216.

Julianingsih, D. K. E. D., \& Yuniarta, G. A. (2020). Pengaruh Intellectual Capital dan Konservatisme Akuntansi Terhadap Kualitas Laba. JIMAT (Jurnal Ilmiah Mahasiswa Akuntansi) Undiksha, 11(2), 159168.Yunengsih, Y., Icih, \& Kurniawan, A. (2018), Pengaruh Ukuran Perusahaan, Net Profit Margin, Debt To Equity Ratio, Kepemilikan Manajerial Dan Reputasi Auditor Terhadap Praktik Perataan Laba (Income Smoothing). Accounting Research Journal of STIE Sutaatmadja, Vol. 2, no. 2, p.31-52.

Zulfiara, P., \& Ismanto, J. (2019), Pengaruh Konservatisme Akuntansi Dan Penghindaran Pajak Terhadap Nilai Perusahaan, Jurnal Akuntansi Berkelanjutan Indonesia, Vol. 2, no.2 